\title{
Evaluácia integrovaného manažmentu Národného parku České Švýcarsko prostredníctvom expertného systému IPAM
}

Peter Repka, Milada Švecová

Envigogika 8 (3) - Recenzované články/Reviewed articles

Publikováno/Published: 15.10. 2013

DOI: http://dx.doi.org/10.14712/18023061.387

\begin{abstract}
Abstrakt
Príspevok je zameraný na zhodnotenie manažmentu Národného parku České Švýcarsko prostredníctvom expertného systému IPAM (Integrated Protected Area Management). Hodnotenie bolo realizované v roku 2012 v spolupráci so zamestnancami Správy národného parku České Švýcarsko. V rámci hodnotenia Národného parku České Švýcarsko sme zistili, že $v$ danej lokalite je vhodne uplatňovaný integrovaný manažment $v$ dvoch fázach: prípravnej fáze a fáze základného plánovania. Integrovaný manažment je $\checkmark$ národnom parku slabšie uplatňovaný vo fáze detailného plánovania, implementačnej fáze a fáze zapojenia do siete. Zlepšenie hodnotených oblastí $v$ rámci jednotlivých fáz manažmentu predpokladáme špeciálne $v$ prehíbení doteraz existujúcej spolupráce $\mathrm{s}$ príbuznými subjektmi $\mathrm{v}$ regiónoch národného parku. Táto spolupráca by mala byt́ zameraná na podporu miestnej ekonomiky s uprednostnením a zameraním sa na tradičné hodnoty regiónu. Je potrebné zefektívnit' spôsob komunikácie so zainteresovanými skupinami (stakeholdermi) v rámci regiónu záujmového územia. Dôležité je tiež nastavenie hodnotiacich mechanizmov a indikátorov úspešnosti plnenia stanovených cielov. Vel'mi dôležité je prehíbenie spolupráce národného parku s možnými partnermi $v$ rámci ekologickej, sociálnej a ekonomickej siete, a to vrátane vzdelávania verejnosti.
\end{abstract}

\section{KI'účové slová}

Manažment chránených území, hodnotenie manažmentu, integrovaný manažment, Národný park České Švýcarsko, ochrana prírody.

Evaluation of integrated management of the Bohemian Switzerland National Park through expert system IPAM

\section{Abstract}

The paper focuses on the evaluation of management of the Bohemian Switzerland National Park through the specialised IPAM (Integrated Protected Area Management) system. The evaluation was undertaken in 2012 in cooperation with the personnel of the Bohemian Switzerland National Park Administration. During the evaluation of the Bohemian Switzerland National Park, we found that integrated management is applied appropriately in two phases in this area: a preparatory phase and a basic planning phase. 
Integrated management is less applied in the national park in the detailed planning phase, the implementation phase and the networking phase. We expect improvement in the evaluated areas in the individual phases of management, especially by strengthening the existing cooperation with related actors in the regions of the national park. This cooperation should be focused on support to the local economy with a priority and focus on the traditional values of the region. The method of communication with stakeholders in the region of interest has to be made more effective. Setting the mechanisms for evaluation and selecting the indicators of success in achieving the defined goals is also very important, as well as strengthening cooperation of the national park with potential partners in the environmental, social and economic network, including educating the public.

\section{Key words}

Management of protected areas, evaluation of management, integrated management, Bohemian Switzerland National Park, nature conservancy. 


\section{Úvod}

Človek za posledné desat́ročie zásadným spôsobom ovplyvnil prírodné prostredie Európy. Odlesňovanie, intenzifikácia pol'nohospodárstva, vysúšanie mokradí, osídlovanie tieto a mnohé iné vplyvy zmenili ráz krajiny takmer na nepoznanie. A predsa aj v týchto zmenených podmienkach sa zachovala pomerne rozsiahla čast́ územia, kde dodnes pretrvávajú tradičné krajinné formy a rozsiahle lesy. Dnes tieto územia čelia problémom ako prežit v modernom svete a uchovat' si hodnoty minulosti (Webster, Holt, Avis, 2002)?

Mnohé z týchto pôvodných území sa stávajú súčastou sústavy Natura 2000, dochádza $v$ nich $k$ prekrytiu dvoch ochranárskych konceptov, a to zachovanie, prípadne zlepšenie, súčasného stavu biotopov, resp. populácií druhov a zároveň ochrany dynamických procesov. $\vee$ praxi to znamená potrebu stanovenia priorít, teda predmetov a ciel'ov ochrany $v$ konkrétnom území. Dlhodobá stratégia starostlivosti o konkrétne územia by mala byt́ výsledkom snahy o vyváženie oboch prístupov (ochrana druhov/biotopov verzus ochrana procesu) $v$ širšom geografickom meradle (Härtel, Křenová, 2009). Z vyššie uvedeného vyplýva, že hlavná oblast' záujmu ochrany prírody je starostlivost' o chránené územia rôzneho stupňa ochrany, ktorá vychádza a opiera sa o exaktné a empirické skúsenosti a poznatky za účelom zachovania biodiverzity a podpory ekologickej stability $v$ ekosystémoch s akceptáciou sociálnych a ekonomických aspektov, ktoré sú súčastou l'udskej spoločnosti. Chránené územia, ktoré je možné podla Medzinárodnej únie ochrany prírody - (IUCN) vyhlásit' za národný park, musia spínat' niekolko kritérií. Prvoradá je $v$ tomto prípade existencia ekosystémov s osobitným vedeckým, náučným a rekreačno-výchovným potenciálom, mimoriadnou estetickou hodnotou a existenciou zákonných opatrení $s$ maximálnou účinnostou, ktorá bráni pokračovaniu $v$ exploatácii a osídl'ovaniu územia národného parku (Vološčuk, Švajda, 2008). Všeobecnými základnými úlohami ochrany prírody je, podla stratégie "Staráme sa o Zem", chránit životodarné prírodné systémy, rozmanitost' života na Zemi a zaistit trvalo udržatel'né využivanie všetkých obnovitel'ných prírodných zdrojov (IUCN, UNEP, WWF 1991). Na dosiahnutie všetkých uvedených podmienok v chránenom území je potrebná implementácia Integrovaného manažmentu. Integrovaný prístup má pri zabezpečovaní udržatel'ného rozvoja chránených území velký význam. Aby však bolo možné vyrovnat sa so zmenami životného prostredia, je potrebné uplatnit' prístup, ktorý napomôže interakciám medzi socioekonomickými a environmentálnymi premennými v širokom rozpätí priestorových a časových kritérií (Fribank, 2005). Hlavným cielom integrovaného manažmentu je vytvorit taký systém, ktorý zjednotí rozvoj jednotlivých socioekonomických aktivít sekologickým, socioekonomickým a kultúrno-historickým potenciálom územia. Integrovaný manažment zaistí elimináciu súčasných a prevenciu vzniku nových ekologických, sociálnych a ekonomických problémov a z dlhodobého hladiska zaistí udržatel'ný rozvoj chráneného územia. Integrovaný manažment je založený na komplexnom výskume územia $v$ troch základných dimenziách - ekologickej, sociálnej a ekonomickej - a na skúmaní súvislostí a vztahov medzi jednotlivými dimenziami. Snahou je zladit' rozvoj uvedených dimenzií s ciel'om dosiahnut' rovnakých životných podmienok a možností pre súčasné a budúce generácie. Nie je možné preferovat́ rozvoj jednej dimenzie napr. ekonomické úžitky - na úkor dimenzie druhej: ekologickej, prípadne sociálnej a pod. (Izakovičová, 2006). Integrovaný manažment sa musí zamerat' rovnako tak na identifikáciu stakeholderov a ich uprednostňovanie. 


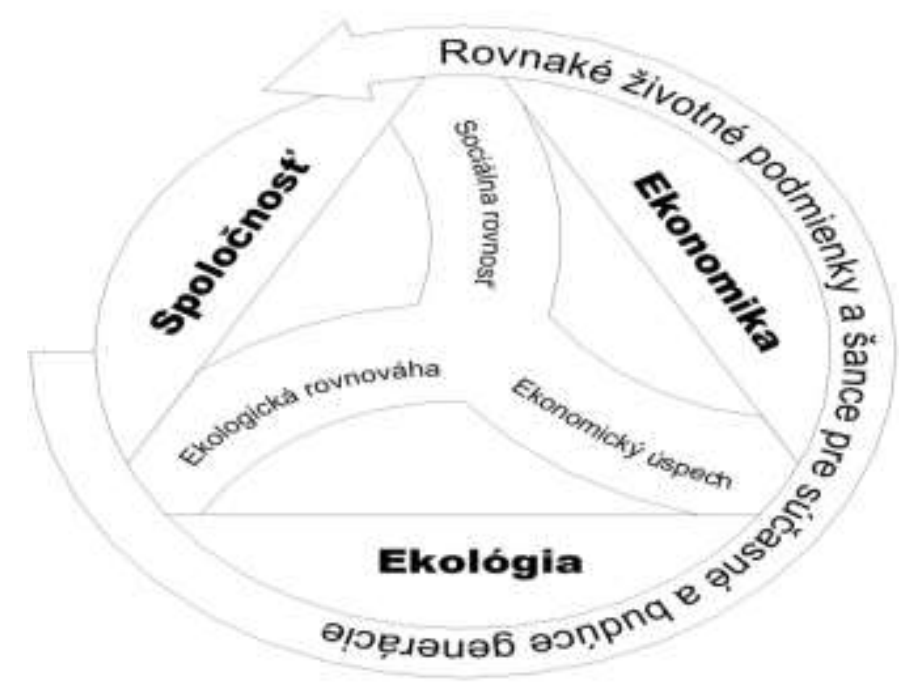

Obr. 1 Princíp integrovaného manažmentu (Upravené podla: Getzner, Jungmeier, Lange, 2010)

Po identifikácii primárnych a sekundárnych stakeholderov národného parku je potrebné zamerat' sa na pozitívne ovplyvňovanie verejnosti a prostredníctvom hodnôt národného parku zvyšovat' environmentálne povedomie. Úlohou národného parku je nájst́ vhodný spôsob pre výchovu návštevníkov a miestneho obyvatel'stva pri akceptácii chránených území. K tomuto účelu slúži strategický dokument Koncepcia environmentálnej výchovy a vzdelávania $v$ národnom parku, ktorého súčastou je vypracovaný školský program zameraný na témy súvisiace $s$ obsahom učebných osnov, tiež kladú dôraz na propagáciu národného parku a systému ochrany prírody. $V$ chránených územiach musí environmentálna výchova zohladnit́ nie len ciele chránených území, ale tak isto globálne a environmentálne problémy. Má efektívne využívat' prírodné dedičstvo chránených území pre bezprostredný kontakt s prírodou. Ďalšou úlohou je priblížit' l'ud'om prírodu ako niečo esteticky príjemné, čo nevyhnutne potrebuje ochranu. Mala by byt́ organizovaná podl'a účastníkov a cielových skupín, ktorým sa prispôsobí metóda a jazyk. Účastníkom sa prezentujú spôsoby zavedenia nových postojov do ich každodenného života a tým zmena spôsobu ich konania. Systém osvety by sa mal rozčlenit́ na ciel'ové skupiny na školách, mimoškolských zariadeniach a pre bežných návštevníkov (Haas, Ondrová, Švajda, 2008). Tieto kroky povedú k rozvoju ekologickej gramotnosti, čiže schopnosti spájat' a uvádzat do súvislosti vedomosti z celej škály odborov, pretože jedine ich skladaním k sebe vzniká celkový obraz o udržatel'nom rozvoji. Potrebu podpory ekologickej gramotnosti prostredníctvom efektívnejšej environmentálnej osvety obyvatel'stva presadzujú a apelujú na ňu mnohí odborníci (Demo et al., 2007; Švecová, 2008). 


\section{Metodika}

Po sumarizácii všetkých relevantných informácií o podmienkach v Národnom parku České Švýcarsko sme na zhodnotenie manažmentu použili metodiku systému Integrovaného manažmentu chránených území IPAM (Integrated Protected Area Management), ktorý bol vyvinutý $v$ rámci projektu Intereg III Cades realizovaného v rokoch 2003-2006. Na navrhnutí tohto systému sa podielal medzinárodný tím expertov na manažment chránených území. Systém vznikol na E. C. O. Institute for Ecology $\checkmark$ Klagenfurte $v$ Rakúsku. Aplikácia a implementácia systému je možná vo všetkých kategóriách chránených území regiónov strednej a východnej Európy, medzi ktoré sa radí aj Česká republika. Systém IPAM je znalostne založený systém, ktorý kombinuje vedomosti o chránenom území s využitím informačných technológií. Kombinuje know-how a dobrú prax založenú na platných podmienkach a predpisoch. Pozostáva z troch častí samohodnotenia (ktoré sa realizuje na základe odpovedí na otázky z dotazníka a zodpovedá ich hlavný manažér chráneného územia - riaditel', alebo zástupca riaditel'a), sady štandardizovaných odporúčaní (systém IPAM odporučí podla vyhodnotenia odpovedí z dotazníka, aké kroky by bolo vhodné realizovat' $v$ konkrétnom chránenom území pre zlepšenie jeho manažmentu) a poznatkovej bázy (vychádza $z$ reálnych podmienok a poznatkov o konkrétnom chránenom území). Tieto tri časti majú za ciel' poskytnút akúkolvek informáciu potrebnú pre rozvoj konkrétneho chráneného územia. Samohodnotenie predstavuje kontrolný zoznam otázok (položených respondentom, $\checkmark$ našom prípade námestníkovi a vedúcemu oddelenia verejných vztáahov Národného parku České Švýcarsko), ktoré pomáhajú identifikovat' a sústredit́ sa na problém a najaktuálnejší stav rozvoja chráneného územia. Štruktúra samohodnotenia, ktorú uvádzame v Tab. 1 vyplýva zo životného cyklu chráneného územia (prípravná etapa, plánovanie, predchádzajúci manažment) a krížovej kontroly zameranej na 29 oblastí manažmentu. Samohodnotenie nakoniec vyústi do správy o vývoji, ktorá zdôrazňuje nedostatky $\checkmark$ plánovaní a manažmente chráneného územia a štandardizované odporúčania. $\mathrm{K}$ hodnoteniu efektívnosti manažmentu sa používa software (Jungmeier, Velik, 2005). Software IPAM je založený na Apache 2.0 webovom serveri, čo je široko používaný HTTP server pre internet, ktorý beží na operačnom systéme Linux. Manažéri chránených území a odborná verejnost́ vstupuje do systému z bežných webových prehliadačov. Identifikácia užívatel'a je vykonávaná na portáli IPAM. Samohodnotenie a vedomostná základňa sú vyvinuté saplikáciou PHP (ale používajú sa tiež, eZ-publish, performed), ktoré sú zakotvené v HTML kóde. Obsah je uložený v databáze My SQL (Jungmeier et al., 2005).

Pri hodnotení manažmentu Národného parku České Švýcarsko systémom IPAM sme postupovali podl'a nasledovných krokov: vytvorenie užívatel'ského profilu na stránke www.ipam.info $\rightarrow$ vytvorenie profilu hodnotenia chráneného územia $\rightarrow$ samohodnotenie a kontrola jednotlivých oblastí manažmentu chráneného územia $v$ prípravnej fáze, fáze základného a detailného plánovania, implementačnej fáze a fáze zapojenia do siete $\rightarrow$ hodnotiaca správa $\rightarrow$ odporúčania. Postup predpokladá znalost' všetkých oblastí manažmentu chráneného územia zo strany respondenta (Vološčuk, Švajda, 2008). $\mathrm{K}$ získaniu vstupných údajov sa používa exploračná metóda - štandardizovaný dotazník, alebo štruktúrované interview, $v$ rámci ktorého sú kladené otázky zo štandardizovaného dotazníka, ktorý bol vyhotovený systémom IPAM (121 otázok zameraných na hodnotenie oblastí manažmentu, ktorých prehlad je uvedený $v$ Tab. 1). Otázky boli zodpovedané námestníkom a tiež vedúcim oddelenia verejných vzt́ahov Národného parku České Švýcarsko (ktorí dôkladne poznajú vývoj národného parku od jeho vyhlásenia až po súčasnost' a sú predstavitel'mi hlavného manažmentu národného parku), ktorí hodnotili jednotlivé aktivity fáz manažmentu trojškálovo - ako ukončené, začaté, ešte nebolo začaté. Získané informácie sú po vložení do systému vyhodnotené softwarom. 
Samohodnotenie je ukončené správou o vývoji, ktorá zdôrazňuje nedostatky v plánovaní a manažmente chráneného územia a štandardizované odporúčania $v$ rámci manažmentu.

Tab. 1 Prehl'ad oblastí hodnotenia manažmentu v systéme IPAM (Upravené podla: Jungmeier et al., 2005).

\begin{tabular}{|c|c|c|}
\hline \multicolumn{2}{|l|}{ Fáza } & Oblasti \\
\hline \multirow{4}{*}{\multicolumn{2}{|c|}{ Prípravná fáza }} & Rozvoj myšlienky a vízie \\
\hline & & Kontrola uskutočnitel'nosti \\
\hline & & Komunikácia a participácia I \\
\hline & & Zapojenie do systému chránených území \\
\hline \multirow{9}{*}{ Fáza plánovania } & \multirow{5}{*}{ Základné plánovanie } & Plánovacia príručka \\
\hline & & Komunikácia a participácia II \\
\hline & & Základný výskum \\
\hline & & Implementačná fáza \\
\hline & & Ustanovenie a založenie \\
\hline & \multirow{4}{*}{ Detailné plánovanie } & Poslanie a základná koncepcia \\
\hline & & Plány manažmentu založené na ekosystéme \\
\hline & & Plán regionálnych ekonomických programov \\
\hline & & Špecifické plánovanie (druhotné plány) \\
\hline \multirow{12}{*}{\multicolumn{2}{|c|}{ Implementačná fáza }} & Personálny a organizačný rozvoj \\
\hline & & Hodnotenie efektívnosti manažmentu \\
\hline & & Financovanie (finančný plán) \\
\hline & & Odhad vplyvov a ich obmedzenie \\
\hline & & Manažment informácií a údajov \\
\hline & & Výskum a monitoring \\
\hline & & Komunikácia a participácia III \\
\hline & & Rozvoj regiónu CHÚ \\
\hline & & Plán spolupráce \\
\hline & & Informácie, interpretácia a výchova \\
\hline & & $\begin{array}{l}\text { Manažment návštevníkov, služieb } \\
\text { a infraštruktúry }\end{array}$ \\
\hline & & Marketing a vztáahy s verejnostou \\
\hline \multirow{4}{*}{\multicolumn{2}{|c|}{ Fáza zapojenia do siete }} & Všeobecné zapojenie do siete \\
\hline & & Zapojenie do ekonomickej siete \\
\hline & & Zapojenie do sociálnej siete \\
\hline & & Zapojenie do ekologickej siete \\
\hline
\end{tabular}




\section{Výsledky}

V Tab. 2-6 zobrazujeme stav plnenia jednotlivých aktivít realizovaných $v$ rámci manažmentu Národného parku České Švýcarsko, ktoré boli hodnotené hlavnými manažérmi (uvedenými v metodike) Národného parku České Švýcarsko trojškálovo. V Obr. 2-6 zobrazujeme percentuálne vyjadrenie plnenia činností a aktivít v rámci jednotlivých oblastí manažmentu Národného parku České Švýcarsko, ktoré sme získali prostredníctvom softwaru IPAM popísaného $v$ metodike. $\vee$ Obr. 7 sme zobrazili komplexné percentuálne vyjadrenie plnenia hlavných oblastí $v$ rámci manažmentu Národného parku České Švýcarsko.

Tab. 2 Prehl'ad hodnotenia aktivít prípravnej fázy námestníkom a vedúcim oddelenia verejných vztáahov Národného parku České Švýcarsko

\begin{tabular}{|c|c|c|c|}
\hline $\begin{array}{l}\text { ešte } \\
\text { nebolo } \\
\text { začaté }\end{array}$ & začaté & dokončené & Prípravná fáza \\
\hline & & & Rozvoj myšlienky a vízie \\
\hline & & $x$ & $\begin{array}{l}\text { Získali ste prehl'ad o významných stakeholderoch, } \\
\text { skupinách a inštitúciách, ktoré budú ovplyvnené, } \\
\text { alebo ich inšpiruje a ovplyvní vznik chráneného } \\
\text { územia? }\end{array}$ \\
\hline & $x$ & & $\begin{array}{l}\text { Iniciovali a podporili ste diskusiu s ciel'om vytvorenia } \\
\text { spoločnej vízie a perspektívy do budúcnosti? }\end{array}$ \\
\hline & $x$ & & $\begin{array}{l}\text { Zahájili ste diskusiu založenú na odbornej expertíze, } \\
\text { ktorá zabráni počiatočným nedorozumeniam } \\
\text { týkajúcich sa obmedzení, financovania alebo } \\
\text { kategorizácie? }\end{array}$ \\
\hline & & & Kontrola uskutočnitel'nosti \\
\hline & $x$ & & $\begin{array}{l}\text { Pripravili ste analýzu popisujúcu problémy a riziká, } \\
\text { ktoré boli identifikované počas diskusného procesu } \\
\text { alebo identifikované expertmi? }\end{array}$ \\
\hline & $x$ & & $\begin{array}{l}\text { Podchytili ste dôležité aspekty (priestor, kultúra, } \\
\text { ekonómia) do jednoduchej štatistickej formy? }\end{array}$ \\
\hline & $x$ & & $\begin{array}{l}\text { Poskytujete nepretržité informácie stakeholderom } \\
\text { (zainteresovaným skupinám) s jasným rozlíšením } \\
\text { faktov a názorov? }\end{array}$ \\
\hline & & $x$ & $\begin{array}{l}\text { Náčrt nedokončených a hotových priestorových } \\
\text { predstáv budúceho chráneného územia. }\end{array}$ \\
\hline & & & Komunikácia a participácia I \\
\hline & $x$ & & $\begin{array}{l}\text { Máte spresnené ciel'ové skupiny (tri kontroly či sú } \\
\text { zahrnuté) a vybudované pravidlá a spôsob } \\
\text { komunikácie (význam osobných stretnutí je }\end{array}$ \\
\hline
\end{tabular}




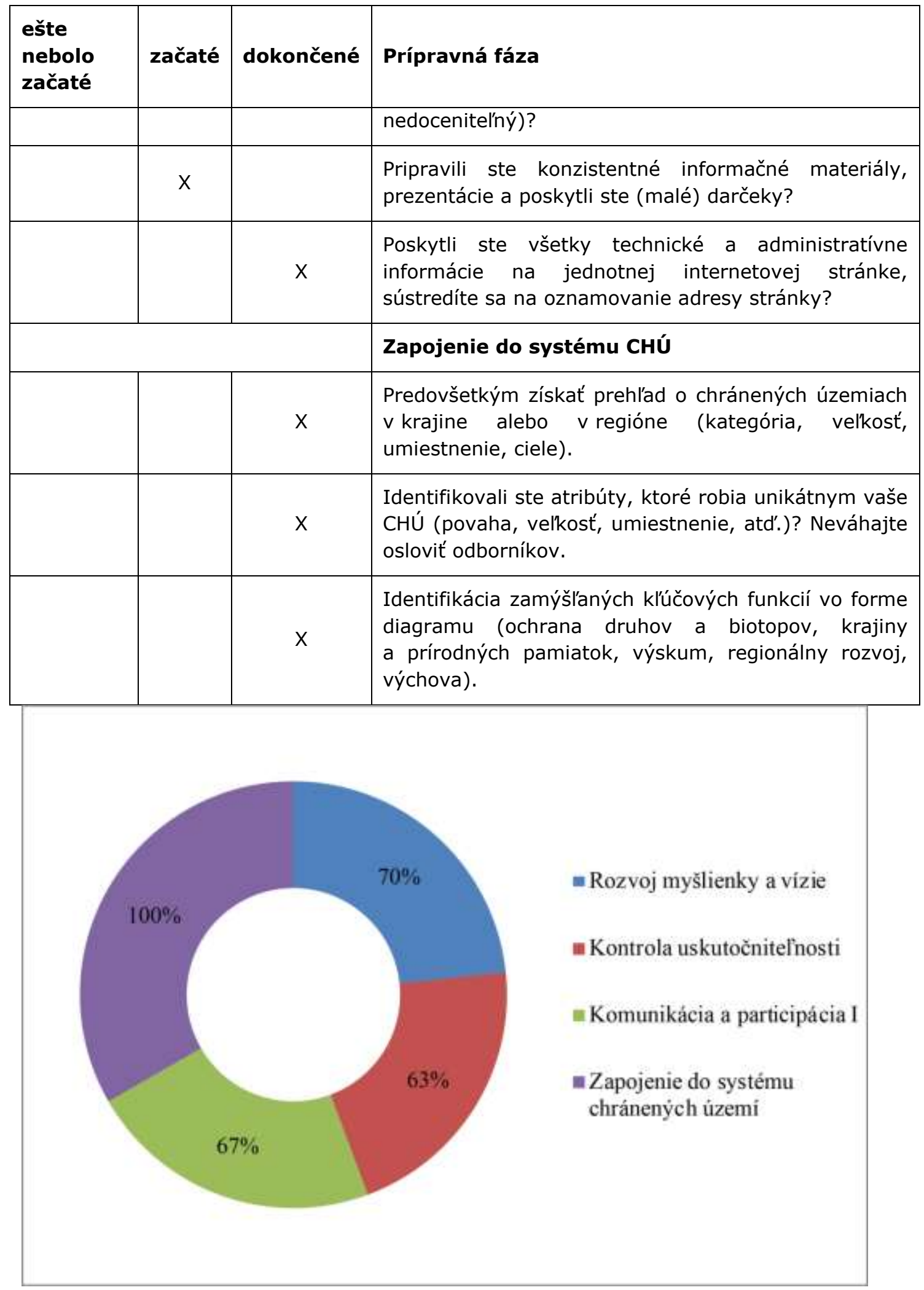

Obr. 2 Percentuálne vyjadrenie hodnotenia oblastí prípravnej fázy (vyjadruje prostredníctvom systému IPAM, na kolko percent sú splnené tieto oblasti) v NP České Švýcarsko 
Tab. 3 Prehl'ad hodnotenia aktivít fázy základného plánovania námestníkom a vedúcim oddelenia verejných vztáahov Národného parku České Švýcarsko

\begin{tabular}{|c|c|c|c|}
\hline $\begin{array}{l}\text { ešte } \\
\text { nebolo } \\
\text { začaté }\end{array}$ & začaté & dokončené & Základné plánovanie \\
\hline & & & Plánovacia príručka \\
\hline & $x$ & & $\begin{array}{l}\text { Pripravili ste vyčerpávajúci prehl'ad zahrňujúci všetky témy, } \\
\text { disciplíny a aspekty plánovania, ktorý určí hlavné problémy, } \\
\text { menej významné aspekty a črty, ktoré sú len kozmetickej } \\
\text { povahy? }\end{array}$ \\
\hline & & $\mathrm{x}$ & $\begin{array}{l}\text { Zostavili ste zoznam všetkých orgánov a inštitúcií zahrnutých } \\
\text { do plánovacieho procesu? Jasne treba oddelit' riadiace, } \\
\text { operačné a kontrolné orgány. }\end{array}$ \\
\hline & $x$ & & $\begin{array}{l}\text { Vytvorit' úplný prehl'ad technických štandardov (počítačových, } \\
\text { o ukladaní údajov, štruktúre výsledkov a prienikov) s ciel'om } \\
\text { ul'ahčit' homogenitu výsledkov a garantovat' správnu syntézu. }\end{array}$ \\
\hline & & & Komunikácia a participácia II \\
\hline & $x$ & & $\begin{array}{l}\text { Poznáte názory, nápady a myšlienky všetkých stakeholderov } \\
\text { a pokúsili ste sa porozumiet' ich účasti a záujmom, aby ste } \\
\text { vedeli identifikovat' klúčových hráčov? }\end{array}$ \\
\hline & $x$ & & $\begin{array}{l}\text { Pripravili ste úplný zoznam všetkých stakeholderov a ich } \\
\text { účasti a záujmov v plánovacom procese? }\end{array}$ \\
\hline & $x$ & & $\begin{array}{l}\text { Pozvali ste významných stakeholderov } \mathrm{k} \text { vytvoreniu kritérií, } \\
\text { aby stanovili podmienky, ktoré budú viest' } \mathrm{k} \text { prehl'adnosti } \\
\text { v procese plánovania? Na tieto kritéria sa musí celý čas } \\
\text { pamätat́. }\end{array}$ \\
\hline & & $x$ & $\begin{array}{l}\text { Poskytujete pravidelné informácie (napr. noviny/obežníky) } \\
\text { a dávate možnost́ pre všetky komentáre a príspevky? }\end{array}$ \\
\hline & $x$ & & $\begin{array}{l}\text { Naviazali ste osobné kontakty s dôležitými stakeholdermi } \\
\text { formou stretnutí, workshopov a rozhovorov? Ponúknete } \\
\text { exkurzie do podobných lokalít? Povzbudzujte stakeholderov } \\
\text { k vyjadreniu ich skúseností, aby poskytli autentické a pravdivé } \\
\text { svedectvá? }\end{array}$ \\
\hline & $x$ & & $\begin{array}{l}\text { Poskytujete všetky technické a administratívne informácie na } \\
\text { vašej domovskej stránke a šírite svoju webovú adresu? } \\
\text { Vybraným skupinám poskytnite prístup k fóram (chránené } \\
\text { heslom). }\end{array}$ \\
\hline & & & Základný výskum \\
\hline & & $\mathrm{x}$ & $\begin{array}{l}\text { Získali ste prehl'ad o regióne formou interview s vybranými } \\
\text { odborníkmi (špecialisti v ekonómii, ekológii a kultúre)? }\end{array}$ \\
\hline
\end{tabular}




\begin{tabular}{|c|c|c|c|}
\hline $\begin{array}{l}\text { ešte } \\
\text { nebolo }\end{array}$ & začaté & dokončené & Základné plánovanie \\
\hline & & $x$ & $\begin{array}{l}\text { Získali ste komplexný prehl'ad existujúcich dát o regióne } \\
\text { (nemusia to byt' vždy len primárne dáta a údaje plánovacieho } \\
\text { procesu)? }\end{array}$ \\
\hline & & $x$ & $\begin{array}{l}\text { Poskytli ste komplexný prehl'ad odpovedajúcej literatúry } \\
\text { o regióne? }\end{array}$ \\
\hline & & & Implementačná fáza \\
\hline & & $x$ & $\begin{array}{l}\text { Máte stanovené pevné hranice a určenú zonáciu v súlade } \\
\text { s požiadavkami kategórie? Príprava na tento akt je náročná } \\
\text { procedúra intenzívnych diskusií so stakeholdermi. }\end{array}$ \\
\hline & & $x$ & $\begin{array}{l}\text { Definovali ste štruktúru organizácie a nechali ste si ju } \\
\text { skontrolovat' externými odborníkmi už v rannej fáze? }\end{array}$ \\
\hline & & $x$ & $\begin{array}{l}\text { Uistili ste sa, že koncept CHÚ korešponduje a zodpovedá } \\
\text { právnemu rámcu a požiadavkám medzinárodnej } \\
\text { kategorizácie? Prispôsobte CHÚ požiadavkám kategórie } \\
\text { územia. }\end{array}$ \\
\hline & & & Ustanovenie a založenie \\
\hline & $x$ & & $\begin{array}{l}\text { Prešli ste právnou procedúrou a objasnili všetky otázky } \\
\text { súvisiace s kompenzáciami, uzatváraním zmlúv a d'alšími } \\
\text { podrobnostami? }\end{array}$ \\
\hline & & $x$ & $\begin{array}{l}\text { Prebrali ste aplikačnú procedúru na úrovni národnej } \\
\text { a medzinárodnej (názvy a označenia)? }\end{array}$ \\
\hline & & $x$ & $\begin{array}{l}\text { Oslavujete „výročie" CHú so zameraním na zvýšenie publicity } \\
\text { a s pod'akovaním všetkým zúčastneným? }\end{array}$ \\
\hline
\end{tabular}




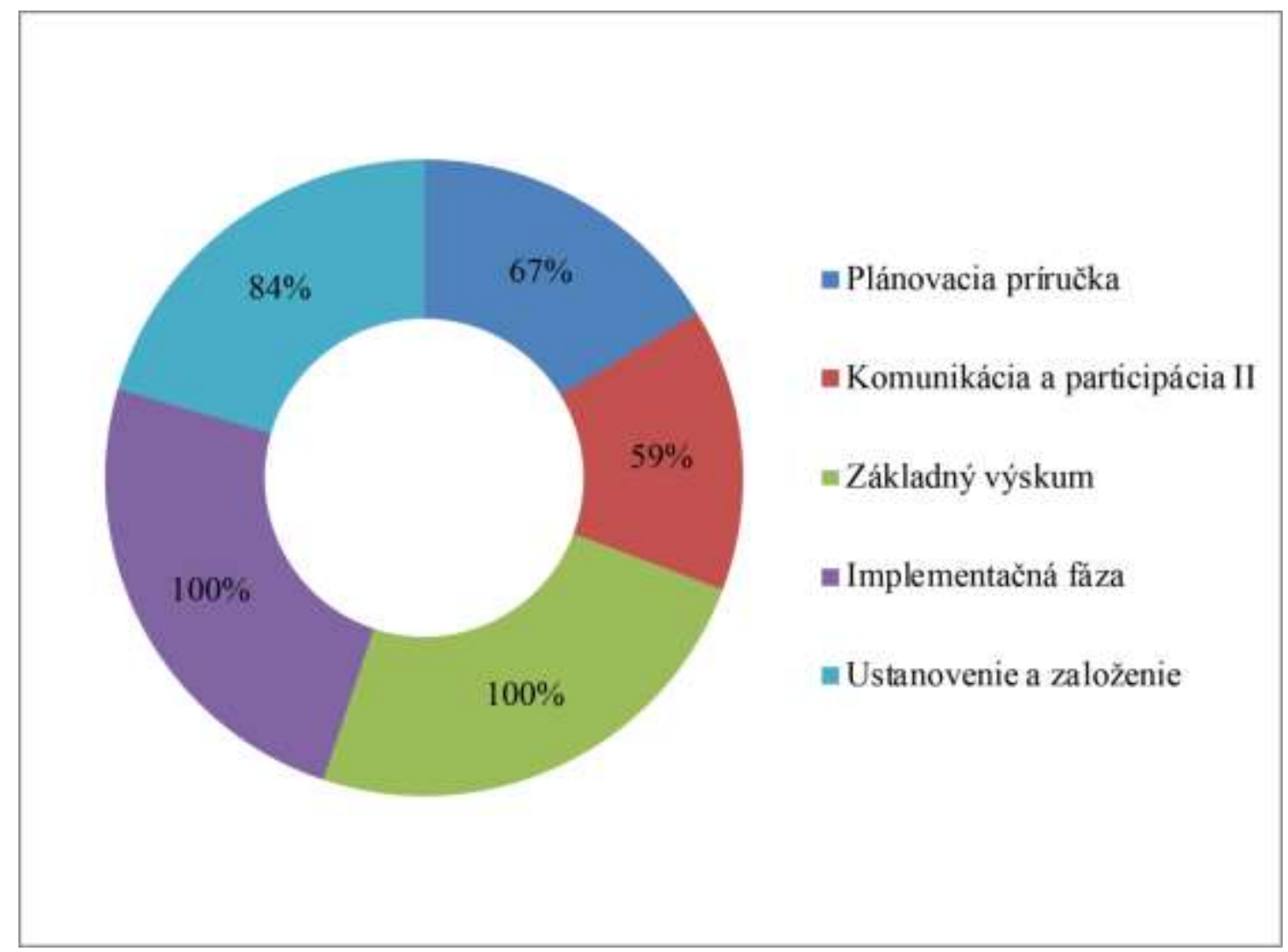

Obr. 3 Percentuálne vyjadrenie hodnotenia oblastí fázy základného plánovania (vyjadruje prostredníctvom systému IPAM, na kolkko percent sú splnené tieto oblasti) v NP České Švýcarsko 
Tab. 4 Prehl'ad hodnotenia aktivít fázy detailného plánovania námestníkom a vedúcim oddelenia verejných vztáahov Národného parku České Švýcarsko

\begin{tabular}{|c|c|c|c|}
\hline $\begin{array}{l}\text { ešte } \\
\text { nebolo } \\
\text { začaté }\end{array}$ & začaté & dokončené & Detailné plánovanie \\
\hline & & & Poslanie a základná koncepcia \\
\hline & & $\mathrm{x}$ & $\begin{array}{l}\text { Pripravili ste filozofiu klúčových hodnôt a ciel'ov lokality ako } \\
\text { súčast' participatívneho procesu? }\end{array}$ \\
\hline & & $\mathrm{x}$ & $\begin{array}{l}\text { Vyvíjate dlhodobé perspektívy } \mathrm{k} \text { dosiahnutiu cielov } \\
\text { v participatívnom procese? }\end{array}$ \\
\hline & & $\mathrm{x}$ & $\begin{array}{l}\text { Pripravili ste Corporate Identity (CI), ktorý vyjadruje } \\
\text { a podporí identitu lokality? }\end{array}$ \\
\hline & & & Plány manažmentu založené na ekosystéme \\
\hline & & $\mathrm{x}$ & $\begin{array}{l}\text { Získali ste jasný prehl'ad ciel'ov ochrany, ich geografické } \\
\text { umiestnenie, status ochrany a riziká, ktorým čelia? }\end{array}$ \\
\hline & & $x$ & $\begin{array}{l}\text { Pripravili ste súbor opatrení, ktoré sú prispôsobené } \\
\text { požiadavkám majitel'ov a užívatel'ov pôdy, avšak s prioritou } \\
\text { ochrany? }\end{array}$ \\
\hline & & $\mathrm{x}$ & $\begin{array}{l}\text { Spoločne ste zhodnotili plánovaný program oproti } \\
\text { finančnému rámcu, aby sa predišlo následnému "trpkému } \\
\text { prebudeniu"? }\end{array}$ \\
\hline & $x$ & & $\begin{array}{l}\text { Vyvinuli ste jasný súbor indikátorov, hodnotiacich } \\
\text { úspešnost'? Pripravili ste jednoduchý, ale efektívny } \\
\text { monitorovací systém? }\end{array}$ \\
\hline & $\mathrm{x}$ & & $\begin{array}{l}\text { Tri veci zabezpečia celkový úspech činnosti: po prvé - } \\
\text { diskusia so stakeholdermi, po druhé - diskusia so } \\
\text { stakeholdermi a po tretie - diskusia so stakeholdermi. }\end{array}$ \\
\hline & & & Plán regionálnych ekonomických programov \\
\hline & $x$ & & $\begin{array}{l}\text { Rozvíjate a poskytujete jasný obraz silných a slabých } \\
\text { stránok, možností a hrozieb pre ekonomický rozvoj regiónu } \\
\text { CHÚ? }\end{array}$ \\
\hline$x$ & & & $\begin{array}{l}\text { Identifikujte požiadavky spotrebitel'ov a vytvorte portfólio } \\
\text { služieb a produktov, ktoré možno vyrábat' a budú } \\
\text { podporovat' miestnu ekonomiku. Udržujte základné hodnoty } \\
\text { regiónu a získajte pridanú hodnotu z miestnej a regionálnej } \\
\text { špecifickej ponuky tovaru (ŠPT). }\end{array}$ \\
\hline & $x$ & & $\begin{array}{l}\text { Vytvorili ste program pre prezentáciu, propagáciu a predaj } \\
\text { regionálnych produktov a služieb blízkych manažmentu } \\
\text { CHÚ? }\end{array}$ \\
\hline
\end{tabular}




\begin{tabular}{|c|c|l|l|}
\hline $\begin{array}{l}\text { ešte } \\
\text { nebolo } \\
\text { začaté }\end{array}$ & začaté & dokončené & Detailné plánovanie \\
\hline & $\mathrm{X}$ & $\begin{array}{l}\text { Podporujete a stimulujete vybrané dobré investície } \\
\text { a udržiavate si externých odborníkov vyberajúcich } \\
\text { a hodnotiacich aktivity a projekty? }\end{array}$ \\
\hline & $\mathrm{X}$ & \begin{tabular}{l} 
Špecifické plánovanie (druhotné plány) \\
\hline $\mathrm{X}$
\end{tabular} & $\begin{array}{l}\text { Pripravili ste komplexný prehl'ad plánovania, ktoré by mohlo } \\
\text { ovplyvit CHÚ (regionálne plány, ochrana pred živelnými } \\
\text { pohromami, dopravné plány, atd'.)? }\end{array}$ \\
\hline & $\begin{array}{l}\text { Pripravili ste administratívne a technické zosúladenia medzi } \\
\text { špecifickými plánovacími orgánmi? }\end{array}$ \\
\hline
\end{tabular}

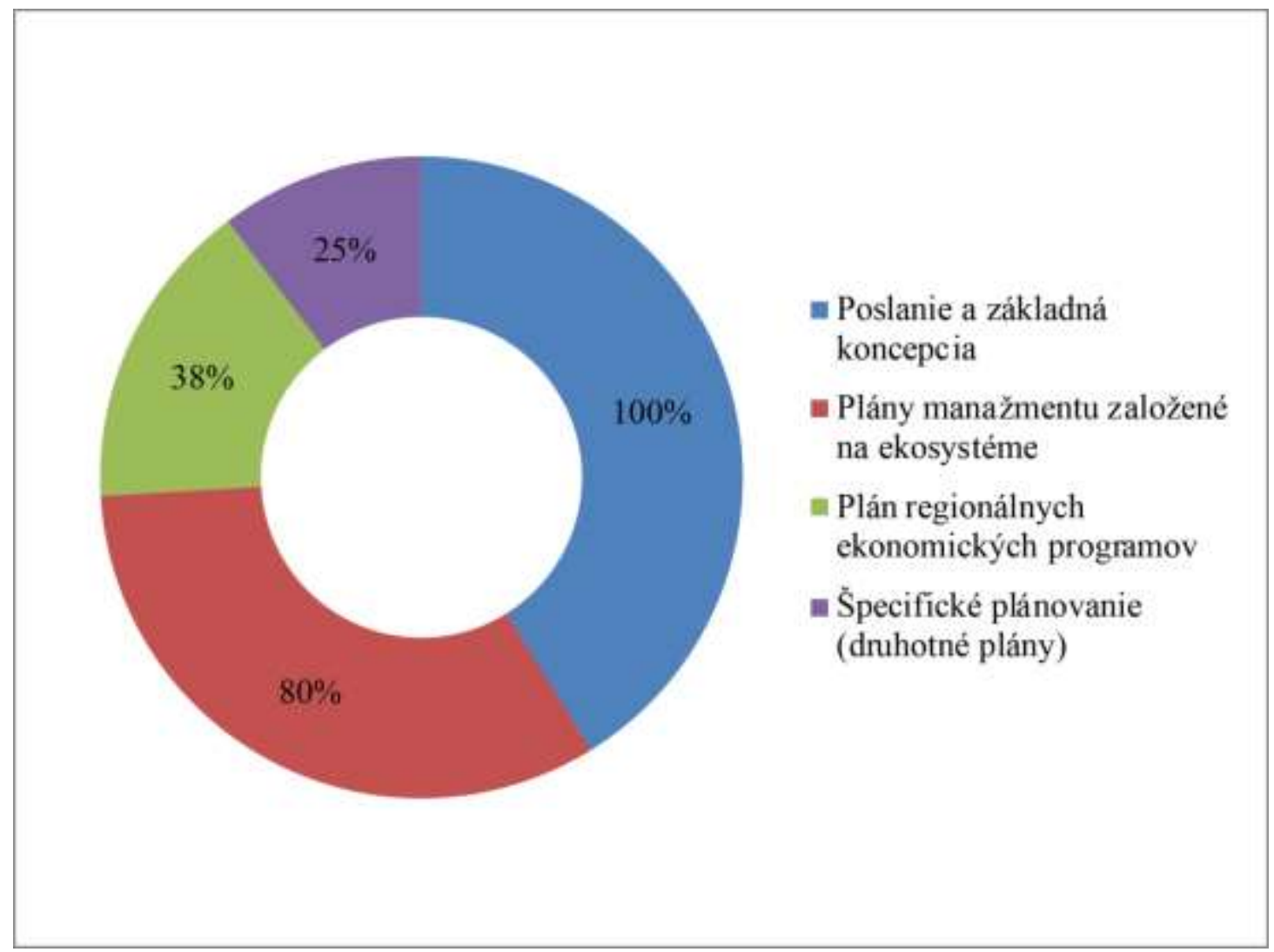

Obr. 4 Percentuálne vyjadrenie hodnotenia fázy detailného plánovania (prostredníctvom systému IPAM, na kolko percent sú splnené tieto oblasti) v NP České Švýcarsko 
Tab. 5 Prehlad hodnotenia aktivít implementačnej fázy námestníkom a vedúcim oddelenia verejných vztáahov Národného parku České Švýcarsko

\begin{tabular}{|c|c|c|c|}
\hline $\begin{array}{l}\text { ešte } \\
\text { nebolo } \\
\text { začaté }\end{array}$ & začaté & dokončené & Implementačná fáza \\
\hline & & & Personálny a organizačný rozvoj \\
\hline & & $x$ & $\begin{array}{l}\text { Zriadili ste pravidlá organizácie a vytvorili ste komplexný } \\
\text { plán inštitúcie (vrátane zodpovedností osôb a kompetencií, } \\
\text { osoby/tímy, procesy)? }\end{array}$ \\
\hline & & $\mathrm{x}$ & $\begin{array}{l}\text { Vytvorili ste jasný plán pre personál s ohl'adom na funkcie, } \\
\text { kompetencie, vzdelanie a možnosti budúceho rozvoja? }\end{array}$ \\
\hline & & $x$ & $\begin{array}{l}\text { Získavate mladý personál, mladé regionálne osobnosti } \\
\text { s ciel'om získat' nové myšlienky a nápady, nových členov } \\
\text { do tímu a vychovat' absolventov? }\end{array}$ \\
\hline & & & Hodnotenie efektívnosti manažmentu \\
\hline & $x$ & & $\begin{array}{l}\text { Pripravili ste rámec pre hodnotenie efektívnosti } \\
\text { manažmentu v CHÚ (poslanie - plánovanie - vstupy - } \\
\text { proces - výstupy - výsledok)? }\end{array}$ \\
\hline $\mathrm{x}$ & & & $\begin{array}{l}\text { Vytvorili ste súbor indikátorov pre hodnotenie úspešnosti } \\
\text { a postupu v súlade s ciel'mi? }\end{array}$ \\
\hline $\mathrm{x}$ & & & $\begin{array}{l}\text { Predstavili ste účinné cesty monitorovania indikátorov } \\
\text { úspešnosti? }\end{array}$ \\
\hline & & & Financovanie (finančný plán) \\
\hline & $\mathrm{x}$ & & $\begin{array}{l}\text { Máte pripravený zoznam výhod, ktoré chcete ponúknut } \\
\text { návštevníkom? }\end{array}$ \\
\hline & $\mathrm{x}$ & & $\begin{array}{l}\text { Máte vytvorenú finančnú stratégiu (ako získat' nové zdroje } \\
\text { a ako získané finančné zdroje povedú k dosiahnutiu } \\
\text { vytýčených cielov)? }\end{array}$ \\
\hline $\mathrm{x}$ & & & $\begin{array}{l}\text { Iniciujete nové spôsoby financovania, napr. reklama, } \\
\text { vstupné, licencie (oficiálny poskytovatel' } \mathrm{CHÚ} \text { )? }\end{array}$ \\
\hline & & $\mathrm{x}$ & $\begin{array}{l}\text { Vytvorili ste detailný ročný plán príjmov (oficiálny } \\
\text { rozpočet, dary, sponzori, dotácie) a výdavkov? }\end{array}$ \\
\hline & & & Odhad vplyvov a ich obmedzenie \\
\hline & & $\mathrm{x}$ & $\begin{array}{l}\text { Máte vypracovaný komplexný prehl'ad obmedzení } \\
\text { a hodnotenie environmentálnych vplyvov, ktoré sú } \\
\text { relevantné pre vaše CHÚ (je možné odvodenie z rôznych } \\
\text { právnych otázok a mimo vašej zodpovednosti)? }\end{array}$ \\
\hline
\end{tabular}




\begin{tabular}{|c|c|c|c|}
\hline \multirow[t]{3}{*}{$\begin{array}{l}\text { ešte } \\
\text { nebolo } \\
\text { začaté }\end{array}$} & začaté & dokončené & \multirow{2}{*}{$\begin{array}{l}\text { Implementačná fáza } \\
\text { Ponúkate možnost' dat' projekt alebo nápad skontrolovat } \\
\text { ako špecializovanú službu, ktorú poskytne orgán alebo } \\
\text { vedenie CHÚ? }\end{array}$} \\
\hline & & $\mathrm{x}$ & \\
\hline & & $\mathrm{x}$ & $\begin{array}{l}\text { Máte vybudovaný jasný postup ( } \quad \text { súlade } \\
\text { s odpovedajúcimi právnymi predpismi a obmedzeniami) } \\
\text { pre odhad vplyvu a zaistenie transparentnosti v postupoch } \\
\text { a hodnoteniach? }\end{array}$ \\
\hline & & & \multirow{2}{*}{$\begin{array}{l}\text { Manažment informácií a údajov } \\
\text { Pripravili ste vhodnú podporu pre EDP (elektronické } \\
\text { spracovanie údajov) pre administratívne a manažérske } \\
\text { aktivity? }\end{array}$} \\
\hline & & $x$ & \\
\hline & & $x$ & $\begin{array}{l}\text { Zaistili ste komplexný prehl'ad údajov a materiálov } \\
\text { relevantných k danému CHÚ? }\end{array}$ \\
\hline & & $\mathrm{x}$ & $\begin{array}{l}\text { Ste prepojení do retéazca sietí s najnovšími digitálnymi } \\
\text { informáciami (letecké snímky, katastrálne plány, } \\
\text { odpovedajúce geografické informácie, databázy, atd'.)? }\end{array}$ \\
\hline & & & Výskum a monitoring \\
\hline & & $\mathrm{x}$ & $\begin{array}{l}\text { Pripravili ste prehl'ad o druhoch výskumu, ktorý je } \\
\text { potrebný vo vašom CHÚ (oblasti a typy výskumu)? } \\
\text { Výskumný profil? }\end{array}$ \\
\hline & & $\mathrm{x}$ & $\begin{array}{l}\text { Zaistili ste podrobný popis potrieb v súvislosti } \\
\text { s výskumom a inventarizáciu všetkých zdrojov potrebných } \\
\text { pre vedeckú prácu? }\end{array}$ \\
\hline & & $x$ & $\begin{array}{l}\text { Zriadili ste dlhodobý monitorovací program, ktorý je } \\
\text { indikatívny, praktický a súvisí s vašimi ciel'mi? }\end{array}$ \\
\hline & & & \multirow{2}{*}{$\begin{array}{l}\text { Komunikácia a participácia III } \\
\text { Zahrnuli ste na základe postupných procesov komunikácie } \\
\text { a participácie s odpovedajúcimi rozhodovacími, } \\
\text { výkonnými, konzultatívnymi a kontrolnými orgánmi všetky } \\
\text { odpovedajúce záujmy a stakeholderov? }\end{array}$} \\
\hline & $\mathrm{x}$ & & \\
\hline $\mathrm{x}$ & & & $\begin{array}{l}\text { Pravidelne poskytujete technické informácie pre } \\
\text { stakeholderov, rozhodovacie orgány a VIP? }\end{array}$ \\
\hline & & & Rozvoj regiónu chráneného územia \\
\hline \multirow[t]{2}{*}{$\mathrm{x}$} & & & $\begin{array}{l}\text { Implementovali ste postupnými krokmi regionálny } \\
\text { ekonomický program so stálou reguláciou a revíziami? }\end{array}$ \\
\hline & $\mathrm{x}$ & & Vybudovali ste CHÚ ako regionálny informačný zdroj \\
\hline
\end{tabular}




\begin{tabular}{|c|c|c|c|}
\hline $\begin{array}{l}\text { ešte } \\
\text { nebolo }\end{array}$ & začaté & dokončené & Implementačná fáza \\
\hline & & & $\begin{array}{l}\text { v zmysle poskytnutia know - how pre udržatel'ný } \\
\text { regionálny rozvoj (napr. subvenčný portál)? }\end{array}$ \\
\hline & $\mathrm{x}$ & & $\begin{array}{l}\text { Založili ste dlhodobú partnerskú spoluprácu s regionálnymi } \\
\text { výrobcami tovarov a služieb? }\end{array}$ \\
\hline & $\mathrm{x}$ & & $\begin{array}{l}\text { Podporujete CHÚ ako obchodnú značku a teda známku pre } \\
\text { lokálne tovary a služby? }\end{array}$ \\
\hline & & & Plán spolupráce \\
\hline & & $\mathrm{x}$ & $\begin{array}{l}\text { Chápete riadenie CHÚ ako dlhodobý proces, ktorý } \\
\text { potrebuje stále vylepšovanie získavaním know - how } \\
\text { a zapojením do siete pre výmenu skúseností? }\end{array}$ \\
\hline & & $\mathrm{x}$ & $\begin{array}{l}\text { Starostlivo vyberáte najlepšie možnosti pre medzinárodnú } \\
\text { spoluprácu (partnerská spolupráca, patronáty, projekty, } \\
\text { výmeny zamestnancov)? }\end{array}$ \\
\hline & & $x$ & $\begin{array}{l}\text { Máte zaistenú dlhodobú spoluprácu CHÚ s rôznymi } \\
\text { partnermi (veda, ekonomika, kultúra, výchova, atd'.)? }\end{array}$ \\
\hline & & & Informácie, interpretácia a výchova \\
\hline & & $\mathrm{x}$ & $\begin{array}{l}\text { Definovali ste hlavné základné poslania, ciel'ové skupiny } \\
\text { medzi návštevníkmi a hlavné aktivity? }\end{array}$ \\
\hline & & $x$ & $\begin{array}{l}\text { Máte rovnako tak naviazané neformálne styky } \\
\text { s vedeckými inštitúciami za účelom aktualizácie poznatkov } \\
\text { a prístupov? }\end{array}$ \\
\hline & & $x$ & $\begin{array}{l}\text { Prebieha výmena informácií a nových aktivít s inými CHÚ } \\
\text { s ciel'om neustálej aktualizácie didaktických prístupov } \\
\text { a výchovných metód? }\end{array}$ \\
\hline & & & Manažment návštevníkov, služieb a infraštruktúry \\
\hline & & $\mathrm{x}$ & $\begin{array}{l}\text { Máte zakotvené aktivity návštevníkov do právnych, } \\
\text { infraštruktúrnych a prírodných podmienok v CHÚ a položil } \\
\text { ste si otázku, čo by malo byt' prípustné, koho prilákat } \\
\text { a čomu sa vyhnút' v rámci participatívneho procesu } \\
\text { (vlastníci pozemkov)? }\end{array}$ \\
\hline & & $\mathrm{x}$ & $\begin{array}{l}\text { Máte pripravený súbor materiálov k sprevádzaniu } \\
\text { návštevníkov územím, na vyhliadkové miesta a po } \\
\text { trasách, ktoré majú prilákat', vzdelávat' a nadchnút } \\
\text { návštevníka (takzvané "horúce body"), pričom sa zohl'adni } \\
\text { otázka ciel'ových skupín? }\end{array}$ \\
\hline & & $x$ & $\begin{array}{l}\text { Poskytujete dobre vyváženú siet́ infraštruktúry (náučné } \\
\text { chodníky, náučné lokality, informačné body, návštevnícke }\end{array}$ \\
\hline
\end{tabular}




\begin{tabular}{|c|c|c|c|}
\hline $\begin{array}{l}\text { ešte } \\
\text { nebolo } \\
\text { začaté }\end{array}$ & začaté & dokončené & Implementačná fáza \\
\hline & & & centrá, atd'.) a zariskovali ste zavedením novej techniky? \\
\hline & & $x$ & $\begin{array}{l}\text { Poskytujete vyvážený program aktivít pre návštevníkov } \\
\text { (v spojení s inými partnermi a komerčnými službami) } \\
\text { napr. sprievodcovské služby, dobrodružné výlety, nočné } \\
\text { prechádzky, vedecké exkurzie, skauting, atd'.)? }\end{array}$ \\
\hline & $x$ & & $\begin{array}{l}\text { Získavate spätnú väzbu od návštevníkov a monitorujete } \\
\text { ich správanie sa, aktivity a rozptýlenie? }\end{array}$ \\
\hline & & & Marketing a vzt'ahy s verejnost'ou \\
\hline & $\mathrm{x}$ & & $\begin{array}{l}\text { Rozumiete, rozvíjate a podporujete meno CHÚ ako značky } \\
\text { a identifikujete spoločný odkaz a poslanie? }\end{array}$ \\
\hline & $\mathrm{x}$ & & $\begin{array}{l}\text { Zaistili ste, aby zamestnanci - profesionáli, ako aj } \\
\text { dobrovol'níci, boli nadšení, schopní a skutoční propagátori } \\
\text { značky CHú? }\end{array}$ \\
\hline & & $x$ & $\begin{array}{l}\text { Pripravili ste komunikačnú stratégiu CHÚ, identifikovali ste } \\
\text { príjemcov a spôsob komunikácie (noviny, spoločenské } \\
\text { udalosti, komerčné akcie, atd'.), hl'adáte spôsoby } \\
\text { tlmočenia imidžu? }\end{array}$ \\
\hline & & $x$ & $\begin{array}{l}\text { Založili ste dlhodobú spoluprácu s médiami, agentúrami } \\
\text { a lokálnymi alebo regionálnymi komunikačnými } \\
\text { a informačnými prostriedkami a pracovníkmi? }\end{array}$ \\
\hline
\end{tabular}




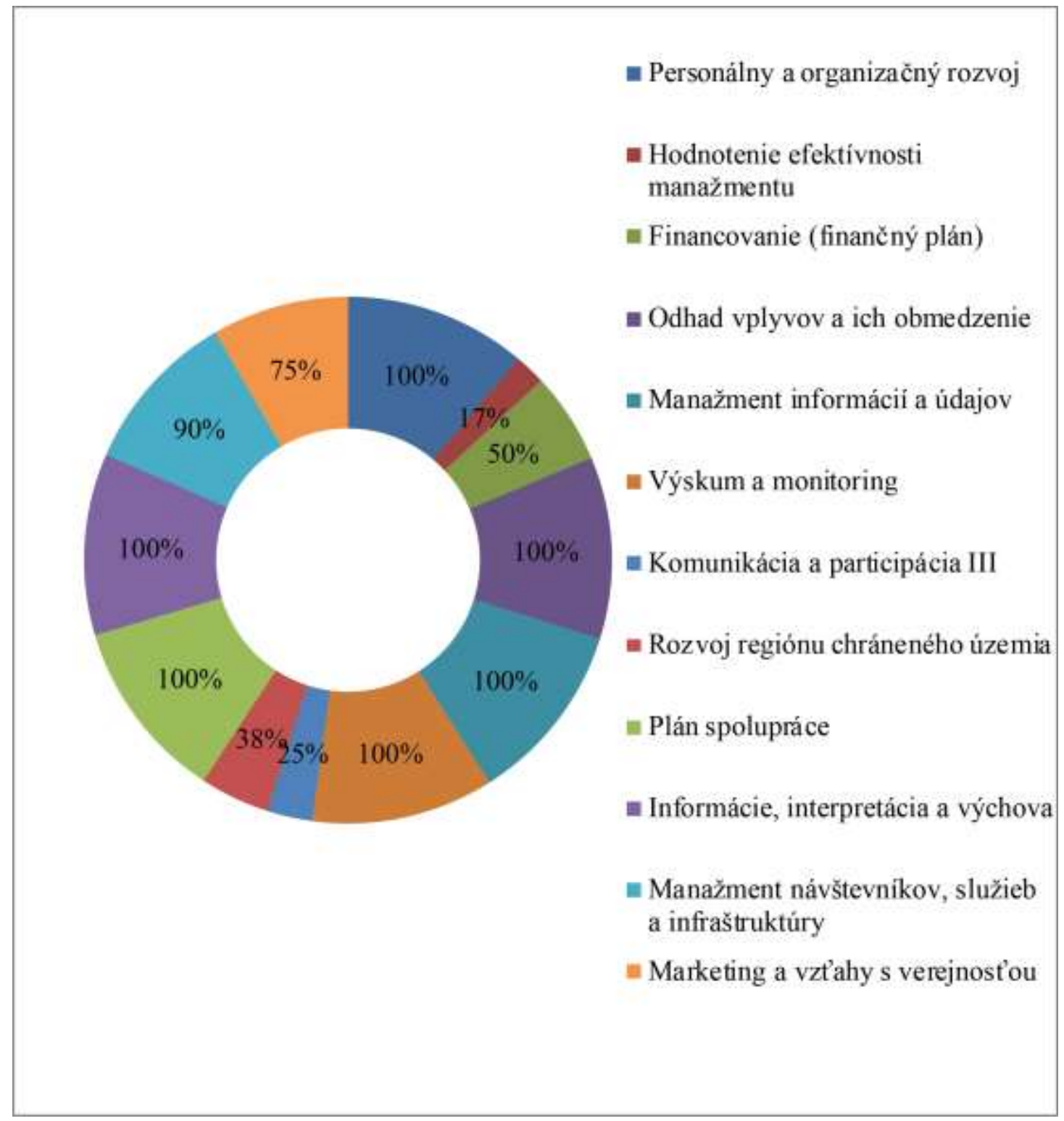

Obr. 5 Percentuálne vyjadrenie hodnotenia implementačnej fázy (vyjadruje prostredníctvom systému IPAM, na kolko percent sú splnené tieto oblasti) v NP České Švýcarsko 
Tab. 6 Prehlad hodnotenia aktivít fázy zapojenia do siete námestníkom a vedúcim oddelenia verejných vztáahov Národného parku České Švýcarsko

\begin{tabular}{|c|c|c|c|}
\hline $\begin{array}{l}\text { ešte } \\
\text { nebolo } \\
\text { začaté }\end{array}$ & začaté & dokončené & Zapojenie do siete \\
\hline & & & Všeobecné zapojenie do siete \\
\hline & $\mathrm{x}$ & & $\begin{array}{l}\text { Načrtli ste „mentálny obraz" o existujúcej sieti chránených } \\
\text { území (partnerov) a popísali ste druh spolupráce? }\end{array}$ \\
\hline \multirow[t]{2}{*}{$\mathrm{x}$} & & & $\begin{array}{l}\text { Identifikovali ste potenciálnu alianciu za účelom rozšírit', } \\
\text { optimalizovat' vašu siet' a návrh akčného plánu? }\end{array}$ \\
\hline & $x$ & & $\begin{array}{l}\text { Využili ste existujúce nástroje a metódy s ciel'om nájst' } \\
\text { nových partnerov? }\end{array}$ \\
\hline & & & Zapojenie do ekonomickej siete \\
\hline \multirow[t]{3}{*}{$X$} & & & $\begin{array}{l}\text { Aktivovali ste siete s ciel'om zabezpečit' nové možnosti } \\
\text { financovania CHÚ? }\end{array}$ \\
\hline & $\mathrm{x}$ & & $\begin{array}{l}\text { Podporili ste akcie, mechanizmy, procedúry pre } \\
\text { spoluvyužívanie existujúcich zdrojov s inými CHú? }\end{array}$ \\
\hline & $x$ & & $\begin{array}{l}\text { Implementovali ste akcie a prepojenie s inými CHÚ za } \\
\text { účelom spoločného zvýšenia úrovne vašich zdrojov? }\end{array}$ \\
\hline & & & Zapojenie do sociálnej siete \\
\hline & $\mathrm{x}$ & & $\begin{array}{l}\text { Posúdili ste úroveň "sociálnej kvalifikácie" (sociálnych } \\
\text { zručností) zamestnancov (členov) správy vášho CHú? } \\
\text { Zhodnotili ste vaše komunikačné zručnosti vo vztahu } \\
\text { komunikácie s "ostatnými"? }\end{array}$ \\
\hline & & $x$ & $\begin{array}{l}\text { Posúdili ste potrebu, možnost' zapojit' sa do siete } s \text { inými } \\
\text { CHÚ? Posúdili ste } v \text { tejto súvislosti vašu pripravenost' } \\
\text { zúčastnit' sa alebo dat' podnet k takejto spolupráci? }\end{array}$ \\
\hline & & & Zapojenie do ekologickej siete \\
\hline$X$ & & & $\begin{array}{l}\text { Poskytujete ekologický profil, ktorý opisuje CHÚ ako uzol } \\
\text { ekologickej siete a prijali ste nástroje a štandardy s cielom } \\
\text { ul'ahčit výmenu informácií? }\end{array}$ \\
\hline
\end{tabular}




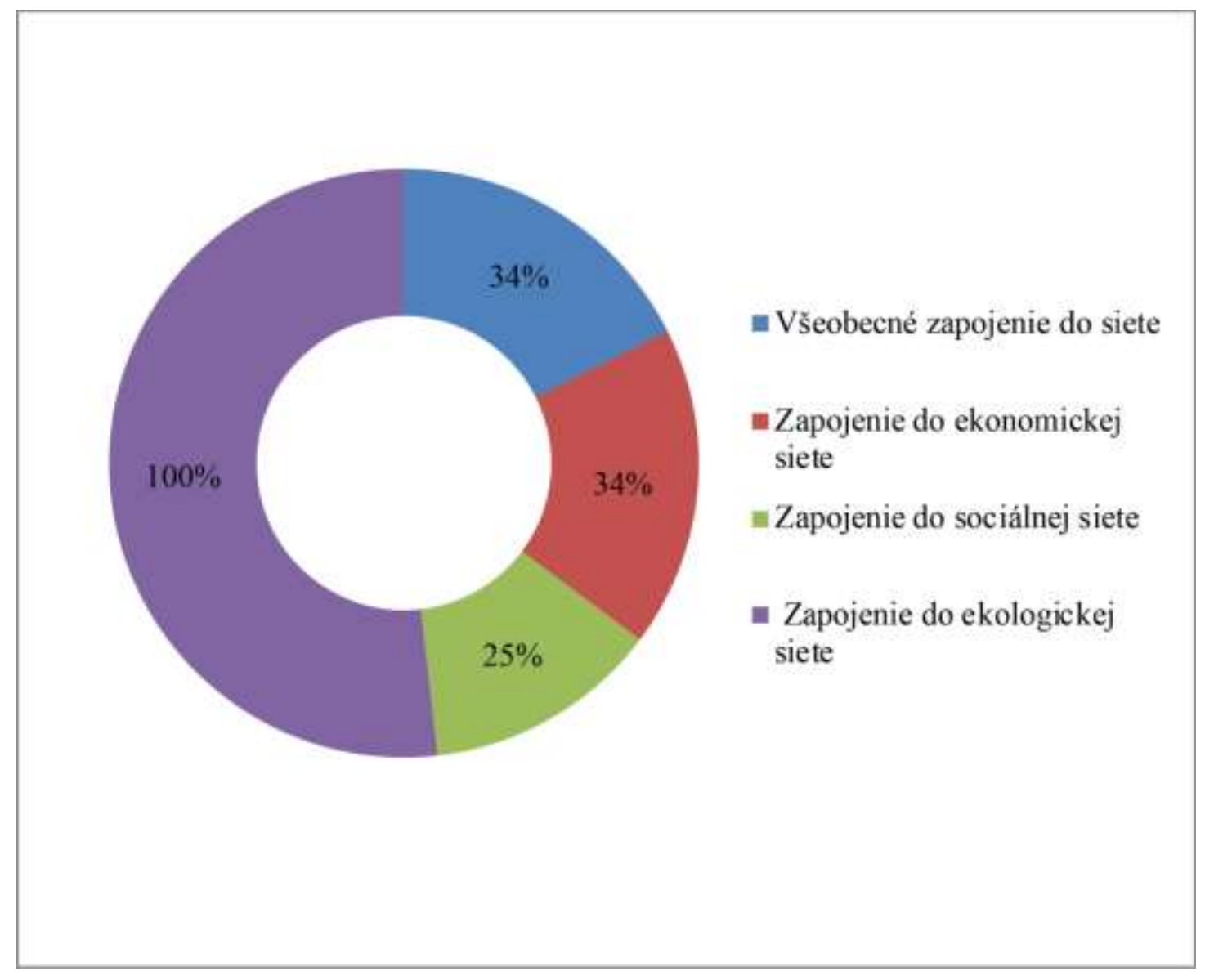

Obr. 6 Percentuálne vyjadrenie hodnotenia fázy zapojenia do siete (vyjadruje prostredníctvom systému IPAM, na kol'ko percent sú splnené tieto oblasti) v NP České Švýcarsko 


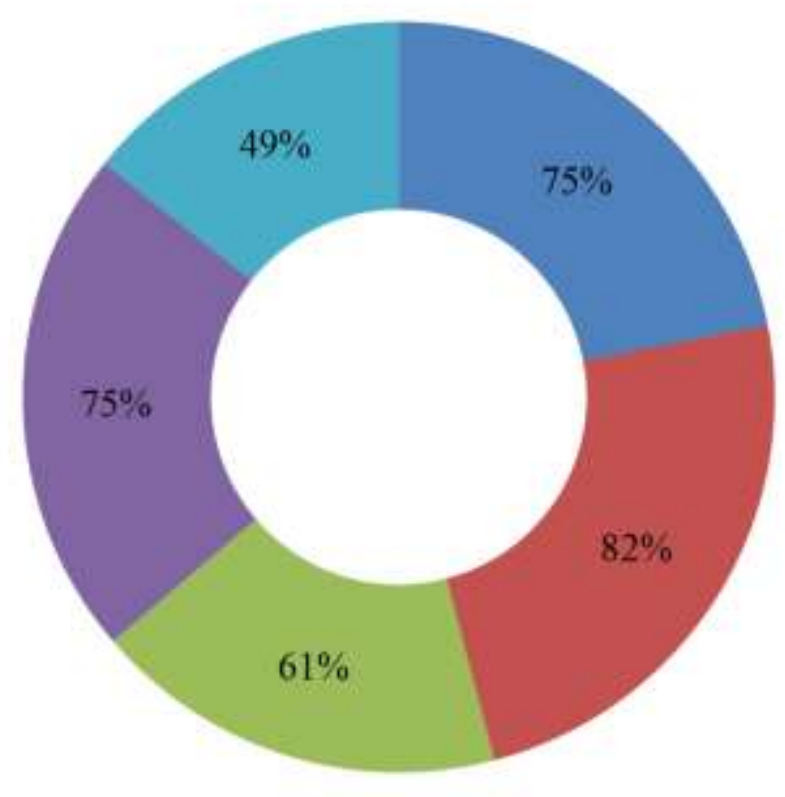

- Pripravná fáza

* Základné plánovanie

= Detailné plánovanie

wimplementačná fáza

= Fáza zapojenia do siete

Obr. 7 Komplexné zhodnotenie fáz manažmentu (vyjadruje prostredníctvom systému IPAM, na kolko percent sú tieto fázy napínané) v NP České Švýcarsko

\section{Diskusia}

Systém IPAM sme zvolili ako nástroj na hodnotenie manažmentu Národného parku České Švýcarsko $z$ viacerých dôvodov. V prvom rade je potrebné poukázat' na to, že $\checkmark$ minulosti sa manažment národných prakov $v$ Českej republike nehodnotil prostredníctvom tohto systému. $\vee$ porovnaní $s$ inými systémami na hodnotenie manažmentu chránených území (ako je napr. Rapid Assesment and Prioritisation Methodology (RAPPAM)) je systém IPAM vo väčšej miere zameraný na hodnotenie vztáahov $\mathrm{s}$ verejnostou, stakeholdermi a rovnako tak sa zameriava na pomenovanie a hodnotenie potrieb jednotlivých ciel'ových skupín (vytváranie benefitov), ktoré chránené územie navštevujú. Špeciálne sa tento systém venuje hodnoteniu environmentálnej výchovy a osvete realizovanej $v$ rámci činnosti chráneného územia. $V$ rámci systému IPAM je možné hodnotit́ každé chránené územie individuálne a hodnotenie nie je obmedzené stupňom ochrany chráneného územia. Systém IPAM hodnotí chránené územie ako celok, so všetkými jeho ekosystémami a podmienkami v ňom. Systém IPAM napomáha znižovat' tlak na manažérov chránených území, ktorý je na nich vytváraný pri rozhodovaní a riadení chráneného územia. Ul'ahčuje a napomáha manažérom pri komplexnom hodnotení manažovania chráneného územia a zároveň napomáha úspešne zaviest́ integrovaný manažment $v$ chránenom území. Integrovaný manažment sa tiež $v$ rámci chránených území zameriava na riešenie vzt́ahov so zainteresovanými skupinami a verejnostou. $\mathrm{Na}$ zhodnotenie vztáahov so zainteresovanými skupinami (stakeholdermi), ktoré je súčastou hodnotenia $v$ rámci hodnotenia IPAM odporúčame použit́ stakeholder management. Je to riadenie vztáahov vytváraných a udržiavaných medzi organizáciou a jej stakeholdermi, ktorí sú alebo môžu byt' aktivitami organizácie ovplyvnení a tak isto samotnú organizáciu môžu istým spôsobom ovplyvnit́ oni sami. Identifikácia stakeholderov obsahuje tri kroky, ako uvádza Zelený (2008) „a to: identifikácia stakeholderov, klasifikácia a uprednostnenie 
stakeholderov a následne analýza a poznávanie stakeholderov." Jedna z metód, ako identifikovat' stakeholderov chráneného územia, je položit' si nasledujúce otázky (Thomas, Midleton, 2003). V akom vzt́ahu sú s chráneným územím? K akému účelu chránené územie používajú a akú má pre nich hodnotu? Aké majú v rámci chráneného územia úlohy a zodpovednosti? Akým spôsobom ich ovplyvní zavádzaný manažment? Aký je vplyv ich aktivít na hodnoty chráneného územia? Stakeholderov môžeme následne po zodpovedaní týchto otázok rozdelit́ na primárnych a sekundárnych (Zelený et al., 2010).

samospráva, vláda, záujmové skupiny, média, verejnost'

(obyvatelia územia NP, ochranného pásma NP a iní), investori,

strategický partneri, dodávatelia, zamestnanci, konkurencia, zákazníci, návštevníci,

regulačné orgány, nevládne organizácie, finančné inštitúcie,

Primárni stakeholderi

Sekundárni stakeholderi

Obr. 8 Primárni a sekundárni stakeholderi (Upravené podla: Zelený et al., 2010)

Zo zhodnotenia jednotlivých fáz manažmentu Národného parku České Švýcarsko vyplýva, že je potrebné posilnit' fázy detailného plánovania, implementačnú fázu a fázu zapojenia do siete. $V$ rámci zlepšenia fázy detailného plánovania je potrebné zamerat́ sa na podporu plánu regionálnych programov. Ďalej identifikovat' najdôležitejšie požiadavky návštevníkov a posilnit́ vytvorenie portfólia produktov a služieb, ktoré môžu byt́ produkované a poskytované za účelom podpory regionálnej ekonomiky a regionálneho hospodárstva. Tieto kroky je nutné podniknút s prihliadnutím na miestne hodnoty a tradičné regionálne služby a produkty (ktoré sú nositel'mi originálnych predajných návrhov). $V$ oblasti špecifického plánovania je potrebné vypracovat́ koncepčné a technické prepojenia jednotného administratívneho a technického modulu medzi riadiacimi orgánmi pre detailnejšie plánovanie, ktoré bude preventívne minimalizovat́ možné negatívne vplyvy na národný park. $V$ rámci zlepšenia implementačnej fázy je potrebné posilnit́ hodnotenie efektivity manažmentu a to formou nastavenia skupiny ukazovatel'ov hodnotiacich úspešnost' a procesy $v$ súlade so stanovenými ciel'mi, ako i monitoringu týchto ukazovatel'ov úspešnosti adekvátnymi metódami. V oblasti financovania je potrebné zamerat' sa na prípravu nových spôsobov financovania ako sú príjmy z distribúcie produktov, vstupných poplatkov a licencií.

V oblasti komunikácie a participácie III je potrebné zamerat' sa na prehodnotenie komunikácie. Je vel'mi dôležité poskytovat' pravidelné technické a odborné informácie pre zúčastnené strany, stakeholderov s rozhodovacími právomocami a vlastníkov nehnutel'ností na území národného parku. $V$ oblasti rozvoja regiónu národného parku je potrebné zamerat́ snahu na vytvorenie a postupnú implementáciu regionálneho hospodárskeho programu, s ktorým sú spojené i d'alšie úsporné opatrenia ako i jeho 
pravidelné vyhodnocovanie, prispôsobovanie a aktualizáciu podla potrieb národného parku. $\checkmark$ rámci fázy zapojenia do siete je potrebné posilnit́ oblast' všeobecného zapojenia do siete, a to identifikáciou potenciálnych partnerov, $s$ ktorými by mohla byt' $v$ budúcnosti nadviazaná plodná spolupráca, rozšírit okruh možných partnerov spolupráce a jeho optimalizácia, ako i vytvorenie akčného plánu pre danú oblast́. V oblasti zapojenia národného parku do ekonomickej siete je potrebné vytvorit' a aktualizovat' prehlad nových možností financovania pre podporu chránených území. Chránené územia z hladiska financovania nie sú samostatne zárobkové subjekty, preto je potrebné ich financovanie podporit' z externých zdrojov (verejných a súkromných). Graf sebahodnotenia môže byt́ vhodným nástrojom, ktorý vyjadrí potrebu nadviazania vztáahov i odhad potenciálnych ekonomických spoločných línií s inými príbuznými organizáciami. Ekonomické hodnotenie (analýza) je vhodným nástrojom pre manažérov chránených území, pretože podporuje snahu hladania finančných zdrojov $v$ tradičných oblastiach, ale rovnako tak napomáha identifikovat' d'alšie zdroje financovania, napomáha odhalit' periférnych stakeholderov (zainteresované skupiny), ktoré môžu rovnako tak pomôct' pri odhal'ovaní hrozieb chráneného územia, indikovat' cesty a zachytit' hodnoty. Môžu byt́ tak isto nápomocní pri poskytovaní manažmentových skúseností. Pomocné aktivity ekonomických aspektov na plánovací manažment sú napríklad: spojenie výskumných programov, projektov, lobovanie u organizácií, ktoré môžu finančne podporit' chránené územie, hladanie darcov, sponzorov, definovanie fondov spoluvyužívajúcich mechanizmy so sietou.

Okrem toho môže zapojenie zainteresovaných strán do finančných aspektov chráneného územia zlepšit' ekonomickú udržatel'nost'.

V oblasti zapojenia do ekologickej a sociálnej siete je nevyhnutné vyhodnotenie úrovne sociálnej kvalifikácie zamestnancov správy chráneného územia. Je potrebné zhodnotit' komunikačné schopnosti a zručnosti. Ako vel'mi potrebné sa javí zlepšovanie marketingu $v$ chránených územiach. $V$ rámci chránených území nie sú definované úlohy manažérov, dôsledkom čoho je nedostatočná komunikácia chránených území s ostatnými subjektmi. Manažéri chránených území sú vystavovaní d’alším komplikáciám pri ich snahe zapojit sa do týchto aktivít. Nezriedka narazia na problém nedostatku zručností a znalostí $v$ oblasti marketingu chránených území. Ako vel'mi naliehavý problém sa na jednej strane vynára nedostatok vzdelávacích príležitostí pre manažérov chránených území v týchto oblastiach. Na strane druhej je nedostatok odborníkov vo vztáahu k verejnosti pracujúcich pre správy chránených území (typické pre chránené územia je, že manažéri sú biológovia, ekológovia a pod.). $V$ tejto súvislosti navrhujeme zvýšit povedomie manažérov chránených území v oblasti lobingu, vztáahov s verejnostou, marketingu a komunikácie. Pre dosiahnutie týchto ciel'ov by mali byt́ použité metodiky organizácií z podnikatel'ského prostredia, ktoré rovnako tak disponujú odborníkmi $v$ oblasti ekonomiky, rozvoja podnikania a styku $s$ verejnostou, s ktorými je vhodné konzultovat. $\mathrm{V}$ neposlednom rade je potrebné realizovat opatrenia pre budovanie kapacít. Snažit́ sa o aktivity realizované spoločne s partnermi z iných oblastí, ako sú média, regionálni developeri a iné komunity. Jasne definované konkrétne komunikačné stratégie a ciele akčného plánu by mohli byt' užitočné pri identifikácii hlavných správ potrebných pre komunikáciu s verejnostou.

\section{Záver}

Všetky výsledky a odporúčania, ktoré sme získali realizovaným výskumom, budú poskytnuté zamestnancom Správy Národného parku České Švýcarsko za účelom ich aplikácie. Implementácia našich odporúčaní a jednotlivých krokov $v$ manažmente $v$ sporných oblastiach povedie $k$ zvýšeniu benefitov pre národný park ako aj pre stakeholderov a návštevníkov $v$ rámci ich vzdelávania a osvety. $\mathrm{V}$ neposlednom rade budú 
nami navrhované zmeny osožné regiónu, $v$ ktorom je národný park situovaný, čo povedie k posilneniu vzájomných väzieb medzi chráneným územím a regiónom.

\section{Pod'akovanie}

Výskum k článku bol financovaný $v$ rámci projektu č. I-12-005-01 s názvom: Uplatnenie integrovaného manažmentu $v$ národných parkoch $v$ podmienkach Slovenskej republiky a Českej republiky, ktorý bol realizovaný v rámci výzvy Univerzitnej grantovej agentúry UMB (UGA UMB).

\section{Zoznam použitej literatúry}

- Demo, M. (2007). Udržatel'ný rozvoj, život v medziach únosnej kapacity biosféry. Nitra: Slovenská pol'nohospodárska univerzita $\vee$ Nitre.

- Firbank, L., \& G, (2005). Striking a new balance betwen agricultural production and biodiversity. Annals of Applied Biology. Volume, 146(2), 163-175. Retrieved from http://www.blackwell-synergy.com/doi/abs/10.1111/j.17447348.2005.040078.x doi:10.1111/j.1744-7348.2005.040078.x

- Getzner, M., Jungmeier, M., \& Lange, S. (2010). People, Parks and Money Stakeholder involvement and regional development: A manual for protected areas. Klagenfurt: Druckerei Theiss.

- Haas, M., Ondrová, E., Švajda, J., (2008). Environmentálna výchova/Environmental education. Žilina: Institute of High Mountain Biology, University of Žilina.

- Härtel, H., Křenová, Z., (2009). Dilema priorit: Chráníme biodiverzitu, nebo procesi?. Ochrana prírody, 17(5), 17-21.

- Izakovičová, Z. a kol., (2006). Integrovaný manažment krajiny II. Bratislava: Ústav krajinnej ekológie SAV.

- Unep, Iucn, Wwf, (1991). Caring for the Earth: Strategy for Sustainable Living. Gland, Switzerland: IUCN.

- Integrated Protected Area Management (IPAM) . . Retrieved from http://www.ipam.info/

- Jungmeier, M., Velik, I., (2005). IPAM Toolbox. Final Report. Study commissioned by: Office of the Carinthia Government Dept. 20, Execution: E.C.O. : Institute for Ecology Ltd.

- Jungmeier, M. et al., (2005). IPAM - Toolbox. Transnational Results (Expert Systém, Toolbox and Best Practice) - Study commissioned by: Office of the Carinthian Government Dept. 20, Execution: E.C.O. Klagenfurt: Institute for Ecology Ltd.

- Švecová, M. (2008) Skúsenosti z krajín EÚ. In Švecová, M., Sásiková, K. (Ed.), Výchova $k$ udržatel'nému rozvoju $v$ podmienkach škôl a jej manažment (pp. 131142). Banská Bystrica: Fakulta prírodných vied UMB v BB. 
- Thomas, L., \& Middleton, H. (2003). Guidelines for Management Planing of Protected Areas. Switzerland and Cambridge. Glad: IUCN.

- Vološčuk, I., Švajda, J., (2008). Monografické štúdie o národných parkoch. Zvolen: Vydavatel'stvo TU vo Zvolene.

- Webster, R., Holt, S., \& Avis, Ch., (2002). Karpaty Správa o stave Karpát vypracovaná v rámci Iniciatívy karpatského ekoregiónu. Bratislava: DTP štúdio a tlač: centrum.

- Zelený, J. (2008). Environmentálne manažérstvo a spoločenská zodpovednost'. Banská Bystrica: Fakulta prírodných vied UMB Banská Bystrica.

- Zelený, J. et al., (2010). Environmentálna politika a manažérstvo organizácií. Banská Bystrica: Nikara.

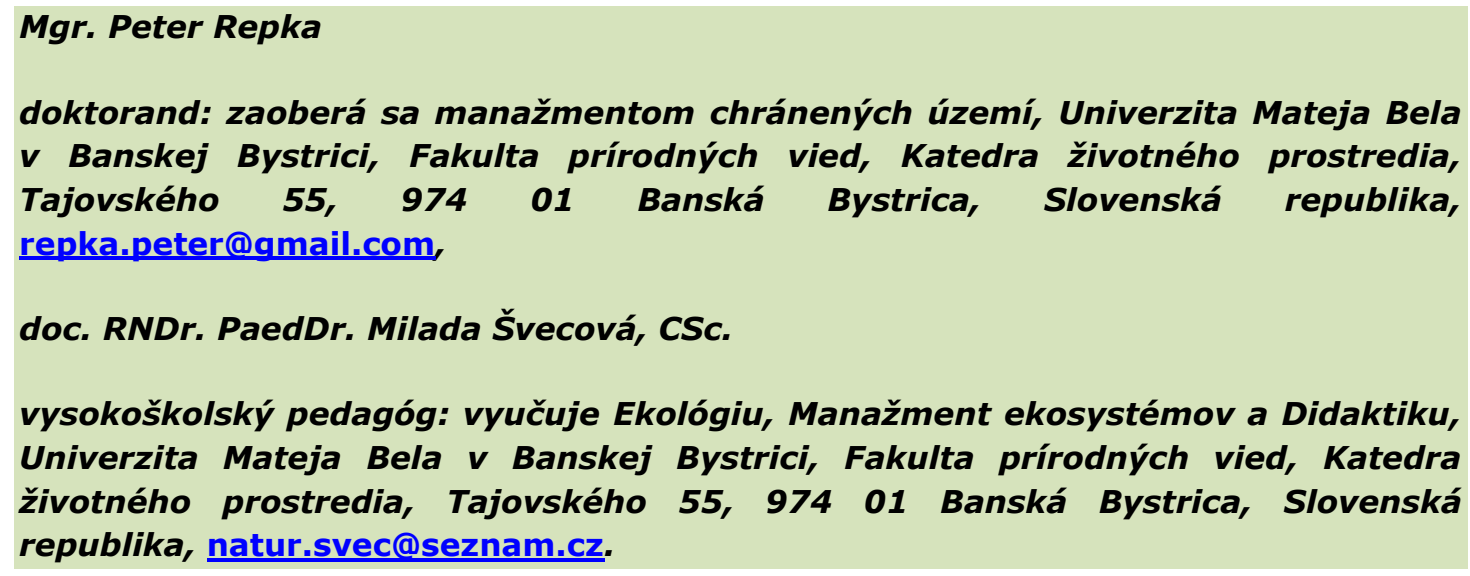

